\title{
FBXW4 wt Allele
}

National Cancer Institute

\section{Source}

National Cancer Institute. FBXW4 wt Allele. NCI Thesaurus. Code C75415.

Human FBXW4 wild-type allele is located in the vicinity of 10q24 and is approximately 85 $\mathrm{kb}$ in length. This allele, which encodes F-box/WD repeat-containing protein 4, is involved in the mediation of both limb morphogenesis and protein catabolism. Mutations in the gene are associated with split-hand/foot malformation type 3. 